\title{
TOWARDS RECIPROCAL DEVERBAL NOUNS IN CZECH: FROM RECIPROCAL VERBS TO RECIPROCAL NOUNS
}

\author{
VÁCLAVA KETTNEROVÁ - MARKÉTA LOPATKOVÁ \\ Charles University, Faculty of Mathematics and Physics, Prague, Czech Republic
}

KETTNEROVÁ, Václava - LOPATKOVÁ, Markéta: Towards reciprocal deverbal nouns in Czech: from reciprocal verbs to reciprocal nouns. Journal of Linguistics, 2019, Vol. 70, No 2, pp. $434-443$.

\begin{abstract}
Reciprocal verbs are widely debated in the current linguistics. However, other parts of speech can be characterized by reciprocity as well - in contrast to verbs, their analysis is underdeveloped so far. In this paper, we make an attempt to fill this gap, applying results of the description of Czech reciprocal verbs to nouns derived from these verbs. We show that many aspects characteristic of reciprocal verbs hold for reciprocal nouns as well.

Keywords: reciprocity, deverbal nouns, lexical and syntactic reciprocal nouns
\end{abstract}

\section{INTRODUCTION}

Reciprocity, as language means encoding mutuality, has attracted much attention in the current linguistics, esp. from a typological perspective ([1], [2], [3]). Despite representing a rather infrequent language phenomenon [4], reciprocity plays a substantial role in the rule based generation of well-formed structures: its prominent position in this task is given by the fact that reciprocity - similarly as diathesis brings about changes in the surface syntactic structure, see the analysis of reciprocity in generative linguistics [5] and in the dependency-oriented Meaning-Text Theory [6]. The most thorough description of reciprocity in Czech is provided by works elaborated within the Functional Generative Description ([7], [8], [9], [10]). Besides these works, reciprocity in Czech is discussed esp. in ([11], [12]).

Reciprocity in Czech can characterize verbs (1), nouns (2), adjectives (3), and adverbs (4). In contrast to verbs, the description of reciprocity with other parts of speech is rather at the beginning.

(1) Manželé se navzájem rušili ze spaní.

'Man and wife disturb each other from sleeping'

(2) vzájemná náklonnost Petra a Jany

'Peter and Jane's mutual affection'

(3) hrdi na sebe

'pride of each other' 


\section{(4) kolmo na sebe \\ 'perpendicularly to each other'}

In this paper, we provide a pilot study of Czech reciprocal nouns derived from verbs, making use of results of the analyses of Czech reciprocal verbs, esp. ([7], [8]), [9]. For their description, we take over a model of a syntactic operation of reciprocalization elaborated for reciprocal verbs [13]. As a theoretical background, the valency theory of the Functional Generative Description is applied ([14], [15], [10]). Due to the limited range of this paper, we focus on nominal structures of deverbal nouns here, while changes characteristic of employing reciprocal nouns in verbal structures, i.e., in reciprocal light verb constructions are left aside.

The paper is structured as follows. First, we classify Czech reciprocal nouns into two groups, lexical and syntactic reciprocal nouns (Sect. 2). Then we discuss the semantic and deep syntactic changes brought about by reciprocalization in nominal structures of deverbal nouns (Sect. 3). Further, we focus on morphosyntactic changes associated with reciprocalization of these nouns (Sect. 4). In Section 5, we explain the role of reciprocalization with lexical and with syntactic reciprocal nouns. Finally, Section 6 comments the distribution of the information on reciprocalization between lexicon and grammar, as two sides of the language description.

\section{LEXICAL VS. SYNTACTIC RECIPROCAL NOUNS}

Similarly as reciprocal verbs, reciprocal nouns can be differentiated into lexical and syntactic reciprocal nouns. Lexical reciprocal nouns contains mutuality in their lexical meaning (e.g. dohoda 'agreement', podoba 'similarity', prátelství 'friendship', rozhovor 'talk'). These deverbal nouns are typically derived from lexical reciprocal verbs, i.e., from those verbs that bear the semantic trait of mutuality in their lexical meaning [13]. This group includes also all deverbal nouns systematically derived by the derivational morphemes -ni/-ti from these verbs (e.g. diskutování 'discussing', chozeni' 'dating', oddělění/oddělováni 'isolating', praní se 'fighting', rozlišení/rozlišováni' 'distinguishing'), see [16].

Further, mutuality can be expressed also by nouns the meaning of which do not bear the semantic trait of mutuality, which, however, allow some of their semantic participants to enter into reciprocity (e.g. dar 'gift', hrozba 'threat', chvála 'praise', soucit 'compassion', radost 'joy', strach 'fear'). ${ }^{1}$ We refer to them as to syntactic reciprocal nouns since mutuality is primarily expressed by syntactic means with them (i.e., the syntactic operation of reciprocalization must be applied for expressing mutuality).

\footnotetext{
${ }^{1}$ The conditions of reciprocalization with verbs is discussed in [7].
} 


\section{SEMANTIC AND DEEP SYNTACTIC ASPECTS OF RECIPROCALIZATION}

The formal model of reciprocalization in Czech has been proposed in [13]. Despite being designed for reciprocal verbs, this model explains reciprocalization with reciprocal nouns derived from these verbs as well, regardless of their type (Sect. 2).

As with reciprocal verbs, reciprocalization operates on valency frames of reciprocal nouns. Its formal model reflects that a pair of semantic participants, ${ }^{2}$ referring to distinct referents, are symmetrically mapped onto valency complementations involved in reciprocity, and as a consequence, onto surface positions provided by these complementations. The complex mapping of semantic participants has both semantic and morphosyntactic effects (Sect. 4). From the semantic perspective, the reciprocal structure portrays a complex event comprising two propositions expressed in a single structure, see e.g. [17].

For example, with the noun puijčka 'loan', derived from the verb pưjčitpf/puijčovat impf 'to lend', the semantic participants Agent and Recipient, corresponding to the ACT and ADDR valency complementations, respectively, can enter into reciprocity, see the valency frame of the noun $(5)^{3}$ and examples (6). Applying the syntactic operation of reciprocalization to the valency frame of this noun leads to the complex mapping of its semantic participants onto the deep and surface syntax, see the scheme in Fig. 1.

(5) pưjčka 'loan': $\mathrm{ACT}_{2,7, \mathrm{pos}, \mathrm{od}+2} \mathrm{ADDR}_{2,3, \mathrm{pos}} \mathrm{PAT}_{2}$

(6) vzájemná půjčka Petra a Pavla / Petrova a Pavlova vzájemná puijčka $\approx$ půjčka peněz Petrovi od Pavla a zároveñ půjčka peněz Pavlovi od Petra

'Peter and Paul's loan of money'

$\approx$ 'Paul's loan of money to Peter and at the same time Peter's loan of money to Paul'

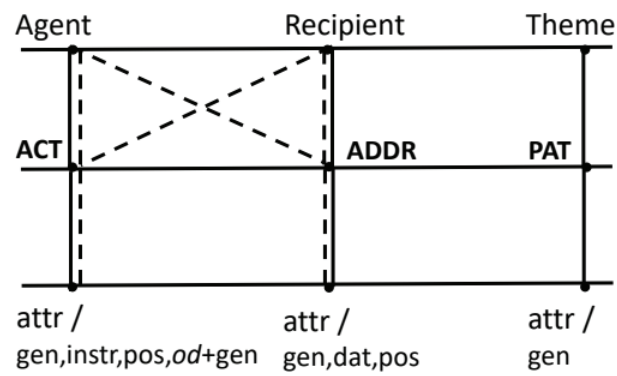

semantic participants

valency complementations

surface positions / morphemic forms

Fig. 1. The scheme of reciprocity of the noun půjck 'loan'; the solid line displays the mapping in unreciprocal structures, the dashed line depicts it in reciprocal ones.

${ }^{2}$ Reciprocity can comprise a triplet of participants as well (e.g., Kolegové se vzájemnè představili. 'Colleagues introduced each other to each other.', vzájemné představení kolegù 'a mutual introduction of colleagues to each other'). However, as these cases are extremely rare, we leave them aside here.

${ }^{3}$ In valency frames of nouns and verbs, we omit the information on obligatoriness of valency complementations (as it is not relevant for our further explanation). 
We can observe that reciprocalization represents the same process with nouns as with verbs. For example, the same scheme, describing relations between the set of semantic participants and the set of valency complementations in Fig. 1, characterizes reciprocalization with the verb pưjčitpp/pưjčovat $t^{i m p f}$ 'to lend', see the valency frame of the verb (7) and examples (8). They differ only in changes in surface positions, given by different structural possibilities of verbs and nouns.

(7) puijčittp/puijčovat timps 'to lend': $\mathrm{ACT}_{1} \mathrm{ADDR}_{3} \mathrm{PAT}_{4}$

(8) Petr a Pavel si vzájemně půjčovali penize.

$\approx$ Petr půjčoval penize Pavlovi a zároveň Pavel půjčoval penize Petrovi.

'Peter and Paul lent money to each other.'

$\approx$ 'Peter lent money to Paul and at the same time Paul lent money to Peter.'

\section{MORPHOSYNTACTIC CHANGES IN RECIPROCAL NOMINAL STRUCTURES}

The complex mapping of semantic participants, characteristic of reciprocalization, is reflected in morphosyntactic changes of valency complementations too. Similarly as with verbs, one surface position affected by reciprocalization is pluralized (Sect. 4.1) while the other is either deleted from the surface, or it is filled with the reflexive pronoun, or with the expression jeden druhý 'each other' (Sect. 4.2); further, reciprocal nouns can be modified by adjectives expressing mutuality (Sect. 4.3).

\subsection{The pluralized surface position}

The pluralized position is provided by that valency complementation of a noun that corresponds to the pluralized position of its respective base verb; this adverbal position is expressed either as the nominative subject, or as the accusative direct object [13]. As the pluralized position of nouns is obligatorily expressed on the surface, it can be considered to be the more prominent one.

The valency complementation corresponding to the pluralized position has typically morphemic forms resulting from changes of the adverbal nominative or accusative to adnominal forms: nominative typically changes into possessive forms, genitive, instrumental, or the prepositional case od + Gen with deverbal nouns and accusative turns into possessive forms and genitive with these nouns [18].

For example, with the noun hádka 'quarrel', reciprocalization involves ACT and ADDR (corresponding to the semantic participants Communicator_1 and Communicator 2, respectively), each providing an attribute position, see the valency frame (9). From these attribute positions, the position given by ACT of the noun is the more prominent one as this ACT corresponds to the nominative ACT of the base verb hádat se $e^{i m p f}$ 'to quarrel', compare frame (9) with the valency frame of the verb 
(11). In reciprocal nominal structures, this attribute position is pluralized. With nouns (similarly as with verbs (12a-c)), it can be pluralized by coordination (10a), by a plural noun (10b), or by a collective noun (10c). As a specific morphemic form of the pluralized complementation, the prepositional case mezi+Instr expands in reciprocal nominal structures, see examples (10d-e).

(9) hádka 'quarrel': $\mathrm{ACT}_{2, \mathrm{pos}} \mathrm{ADDR}_{\mathrm{s}+7} \mathrm{PAT}_{\mathrm{o}+4, \mathrm{dcc}}$

(10) a. hádka Petra ${ }_{\mathrm{ACT}}$ a Jany $_{\mathrm{ACT}}$

'Peter ${ }_{\mathrm{ACT}}$ and Jane's $\mathrm{S}_{\mathrm{ACT}}$ quarrel'

b. hádka kolegi̊ ${ }_{\mathrm{ACT}}$

'quarrel of colleagues ${ }_{\mathrm{ACT}}$ '

c. hádka výboru $u_{\mathrm{ACT}}$

'quarrel of the comittee ${ }_{\mathrm{ACT}}$ '

d. hádka mezi Petrem ${ }_{\mathrm{ACT}}$ a Janou ACT $_{\mathrm{A}}$

'Peter ${ }_{\mathrm{ACT}}$ and Jane's $\mathrm{s}_{\mathrm{ACT}}$ quarrel'

e. hádka mezi kolegy $y_{\mathrm{ACT}}$

'quarrel of colleagues ${ }_{\mathrm{ACT}}$ '

(11) hádat se 'to quarrel': $\mathrm{ACT}_{1} \mathrm{ADDR}_{\mathrm{s}+7} \mathrm{PAT}_{\mathrm{o}+4, \mathrm{dcc}}$

(12) a. Petr $_{\mathrm{ACT}}$ a Jana $_{\mathrm{ACT}}$ se hádali.

'Peter ${ }_{\mathrm{ACT}}$ and Jane ${ }_{\mathrm{ACT}}$ were quarrelling.'

b. Kolegové ${ }_{\mathrm{ACT}}$ se hádali.

'Colleagues $\mathrm{ACT}_{\mathrm{AT}}$ were quarrelling.'

c. Výbor ${ }_{\mathrm{ACT}}$ se hádal.

'The committee ${ }_{\mathrm{ACT}}$ was quarreling.'

Further, with the noun izolace 'isolation' (and its base verb izolovat ${ }^{\text {biasp }}$ 'to isolate'), their semantic participants Part_1 and Part_2, mapped onto the valency complementations PAT and ORIG, respectively, see valency frame (13), can be reciprocalized. From the surface positions given by these nominal valency complementations, the attribute position provided by PAT is the more prominent one, hence pluralized (14), as PAT is in correspondence with the accusative PAT of the base verb izolovat ${ }^{\text {bissp }}$ 'to isolate', expressed as the direct object (15), see also example (16).

(13) izolace 'isolation': $\mathrm{ACT}_{2, \mathrm{pos}} \mathrm{PAT}_{2, \mathrm{pos}} \mathrm{ORIG}_{\mathrm{od}+2}$

(14) vzájemná izolace členů ${ }_{\mathrm{PAT}}$ domácnosti

'household members' ${ }_{\mathrm{PAT}}$ isolation from each other'

(15) izolovat biasp 'to isolate': $\mathrm{ACT}_{1} \mathrm{PAT}_{4} \mathrm{ORIG}_{\mathrm{od}+2, z+2}$

(16) Technologie členyy $y_{\mathrm{PAT}}$ domácnosti vzájemně izolují.

'Technologies isolate household members ${ }_{\mathrm{PAT}}$ from each other.' 


\subsection{The less prominent surface position}

With reciprocal nouns, the less prominent position involved in reciprocalization can remain unexpressed on the surface. If it is present, it can be optionally occupied either by the reflexive pronoun, or by the expression jeden druhy' 'each other', both coreferring with the expression in the more prominent position. These possibilities are conditioned by morphemic forms of the valency complementation providing this position.

As with reciprocal verbs, if this complementation has the form of the prepositional case $s+$ Instr, it is systematically deleted from the surface. The prepositional group $s+$ Instr is the most frequent form of the valency complementation providing the less prominent surface position with lexical reciprocal nouns (see Sect. 2). For example, ADDR in the valency frame of the noun dohoda 'agreement' (17) is subject to reciprocalization with ACT. While ACT is pluralized, ADDR is omitted from the surface, see example (18).

(17) dohoda 'agreement': $\mathrm{ACT}_{2, \text { pos }} \mathrm{ADDR}_{\mathrm{s}+7} \mathrm{PAT}_{\mathrm{na}+6, \mathrm{o}+6, \mathrm{inf}, \mathrm{dcc}}$

(18) dohoda obchodnikü ${ }_{\mathrm{ACT}}$ na ceně kávy

'traders' ${ }_{\text {ACT }}$ agreement on the price of coffee'

A complementation expressed by a simple case or a prepositional case other than $s+$ Inst can be filled by the long form of the reflexive pronoun ${ }^{4}$ or by the expression jeden druhy' 'each other', both coreferring with the more prominent position. In contrast to reciprocal verbs, however, the surface realization of this valency complementation of reciprocal nouns is only optional. For example, with the noun podpora 'support', see valency frame (19), ACT and PAT can be reciprocalized. While ACT is pluralized, PAT can be deleted from the surface (20a), or - if it is present on the surface - it is occupied by the reflexive pronoun in its respective long form (20b), or by the expression jeden druhy' 'each other', from which jeden has the form of genitive, while druhy' is in the respective form prescribed by PAT (excluding genitive or possessive forms) (20c).

(19) podpora 'support': $\mathrm{ACT}_{2, \mathrm{pos}, \mathrm{od}+2} \mathrm{PAT}_{2,3, \mathrm{pos}} \mathrm{EFF}_{\mathrm{v}+6}$

(20) a. Petrova $a_{\mathrm{ACT}}$ a Pavlova $a_{\mathrm{ACT}}$ vzájemná podpora

b. Petrova ${ }_{\mathrm{ACT}}$ a Pavlova ACT $_{\mathrm{AcT}}$ vzájemná podpora sobe $\check{\mathrm{PAT}}_{\mathrm{PAT}}$

c. Petrova $a_{\mathrm{ACT}}$ a Pavlova ${ }_{\mathrm{ACT}}$ vzájemná podpora (jednoho druhému) PAT $_{\mathrm{PA}}$

'Peter ${ }_{\mathrm{ACT}}$ and Paul's $\mathrm{S}_{\mathrm{ACT}}$ support for each other'

${ }^{4}$ Let us emphasize that there is a difference between reciprocal nouns and reciprocal verbs. With reciprocal verbs, besides the long form of the reflexive pronoun, the clitic forms se/si are available in the dative or accusative case, representing positional variants of the pronoun [10]. With reciprocal nouns, only the long forms of the reflexive pronoun can occur [19]. 


\subsection{Modifying adjectives}

A reciprocal noun can be modified by the adjectives vzájemný or společný 'mutual'. The latter one is, however, polysemous: besides the meaning "mutual" (21), it also expresses the meanings "collective, joint" (22) and "common" (23). In the meaning "mutual", the adjective seems to be restricted to lexical reciprocal nouns. For example, while with the lexical reciprocal noun shoda 'agreement', the modifying adjective has the meaning "mutual" (21), with the syntactic reciprocal noun radost 'joy', only the meaning "common" is available (24).

(21) společná shoda mezi nájemníky

'mutual agreement between tenants'

(22) společný koncert Hradišt'anu a sboru Stojanova gymnázia

'a joint concert of Hradišt'an and the choir of Stojanov's grammar school'

(23) společný majetek

'common property'

(24) společná radost týmu z výhry

'common joy of the win'

As for the function of these adjectives, if the less prominent position is expressed on the surface (Sect. 4.2), the adjectives stress the meaning of mutuality $(20 b-c)$. However, if the less prominent position is not expressed on the surface, the adjective is - besides the pluralization of the more prominent position - the only marker of mutuality, removing possible ambiguity between reciprocal and unreciprocal interpretation (20a), (25a) and (27). Without the respective adjectives, these structures can be interpreted as either reciprocal, or unreciprocal with an elided valency complementation. For example, (25b) can have either the reciprocal interpretation, or the unreciprocal one with PAT of the noun sympatie 'sympathy' unexpressed on the surface, see the valency frame (26).

(25) a. naše $e_{\mathrm{ACT}}$ vzájemné sympatie

'our mutual sympathy'

b. naše ${ }_{\mathrm{ACT}}$ sympatie

'our sympathy'

$\approx$ naše $e_{\mathrm{ACT}}$ vzájemné sympatie vs. naše $e_{\mathrm{ACT}}$ sympatie $k$ ostatním $_{\mathrm{PAT}}$

$\approx$ 'our $_{\mathrm{ACT}}$ mutual sympathy vs. our $_{\mathrm{ACT}}$ sympathy for others $_{\mathrm{PAT}}$ '

(26) sympatie 'sympathy': $\mathrm{ACT}_{2, \mathrm{pos}} \mathrm{PAT}_{3, \mathrm{k}+3, \mathrm{pro}+4, \mathrm{~s}+7, \text { vič́i }+3}$

(27) společná dohoda EU a USA

'mutual agreement of EU and USA' 


\section{ROLE OF RECIPROCALIZATION WITH LEXICAL VS. SYNTACTIC RECIPROCAL NOUNS}

With lexical and syntactic reciprocal nouns, reciprocalization plays different roles. With syntactic reciprocal nouns, it is a necessary condition for expressing mutuality. However, with lexical reciprocal nouns, which already bear mutuality in their lexical meaning, its role is different: it allows to make the semantic participants involved in reciprocity equal with respect to their participation (in terms of figure and ground) in the event expressed by a noun, see esp. [20] and [13], stressing that the mapping of participants onto valency positions is not random, compare (28a-b).

For example, the noun rozchod 'split-up' is characterized by two semantic participants, Part_1 and Part_2. As the noun contains mutuality in its lexical meaning, it expresses a mutual event even if its semantic participants are not reciprocalized. In this case, the participant in the more prominent position can be interpreted as more active in the event than the other expressed in the less prominent position; compare examples (30a) with (30b) in which each time a different participant, hrác 'player' or trenér 'trainer', occupies the more prominent position provided by ACT of the noun, see its valency frame (29). However, it does not change the fact that they both are involved in a mutual event. In contrast, when these participants are subject to reciprocalization, their participation in the event is presented as equal (30c).

(28) a. Jak Petr rostl, byla jeho podoba s otcem stále žretelnější.

'As Peter was growing up, his similarity with his father was more and more visible.'

b. ?Jak Petr rostl, byla otcova podoba s ním stále zretelnějšíl.

'As Peter was growing, father's similarity with him was more and more visible.'

(29) rozchod 'split-up': $\mathrm{ACT}_{2, \mathrm{pos}} \mathrm{PAT}_{\mathrm{s}+7}$

(30) a. hráčù $v_{\mathrm{ACT}}$ rozchod s trenérem $\mathrm{PAT}_{\mathrm{PA}}$

'the player's split-up with the trainer'

b. trenérů $v_{\mathrm{ACT}}$ rozchods hráčem $m_{\mathrm{PAT}}$

'the trainer's $\mathrm{ACT}_{\mathrm{ACT}}$ split-up with the player $\mathrm{PAT}_{\mathrm{PAT}}$ '

c. rozchod hráče $e_{\mathrm{ACT}}$ a trenéra $a_{\mathrm{ACT}}$

'split-up of the player $_{\mathrm{ACT}}$ and the trainer ${ }_{\mathrm{ACT}}$ '

\section{RECIPROCALIZATION OF NOUNS IN THE LANGUAGE DESCRIPTION}

Formal theories attempting for generation of well-formed structures carefully distribute the information between lexicon and grammar; the former stores those individual properties of language units that are not predictable from their semantic or 
morphosyntactic features while the latter captures their recurrent patterns which can be described in the form of rules.

As for reciprocity, three types of information should be provided by the lexicon as it is conditioned by semantic and partially by pragmatic factors which are not reflected in the language structure:

- the information on the type of a noun (lexical or syntactic reciprocal noun),

- its valency structure, and

- the information on individual pairs of the valency complementations that can be subject to reciprocalization.

In contrast, surface syntactic changes follow from morphemic forms of the valency complementations involved in reciprocity - they are regular enough to be captured by formal rules stored in the grammar. In addition to morphosyntactic changes of valency complementations, these rules should describe their lexical expression (Sect. 4.1 and 4.2) and the role of adjectives (Sect. 4.3).

\section{CONCLUSION}

In this paper, we have explained principles underlying generation of wellformed reciprocal structures of deverbal nouns that cover their semantic, deep as well as surface syntactic structures. We show that valency frames of both lexical and syntactic reciprocal nouns must be stored in the lexical component of the language description, including the information on those valency complementations which can be reciprocalized. Then detailed rules describing changes in their nominal structures caused by reciprocalization and closely cooperating with rules governing surface formation of unreciprocal structures must be provided by the grammar component.

\section{ACKNOWLEDGEMENTS}

The research reported in this paper has been supported by the GAČR grant No. 18-03984S, Between Reciprocity and Reflexivity: The Case of Czech Reciprocal Constructions. This work has been using language resources distributed by the LINDAT/ CLARIN project of the MŠMT ČR, No. LM2015071.

\section{References}

[1] Nedjalkov, V. P. (ed.) (2007). Reciprocal Constructions. Amsterdam/Philadelphia, John Benjamins.

[2] Evans, N., Gaby, A., Levinson, S. C., and Majid, A. (eds.) (2011). Reciprocals and Semantic Typology. Amsterdam/Philadelphia, John Benjamins. 
[3] König, E., and Gast, V. (eds.) (2008). Reciprocals and reflexives: cross-linguistic and theoretical explorations. Berlin/New York, Mouton de Gruyter.

[4] Maslova, E. (2008). Reflexive encoding of reciprocity. In E. König, V. Gast (eds.), Reciprocals and reflexives: cross-linguistic and theoretical explorations, pages 227-257, Berlin/New York, Mouton de Gruyter.

[5] Reinhart, T., and Siloni, T. (2005). The Lexicon-Syntax Parameter: Reflexivization and Other Arity Operations. Linguistic Inquiry, 36(3), pages 389-436.

[6] Mel'čuk, I. A. (1988). Dependency Syntax: Theory and Practice. Albany, State University of New York Press.

[7] Panevová, J. (1999). Česká reciproční zájmena a slovesná valence. Slovo a slovesnost, 60(4), pages 269-275.

[8] Panevová, J. (2007). Znovu o reciprocitě. Slovo a slovesnost, 68(2), pages 91-100.

[9] Panevová, J., and Mikulová, M. (2007). On reciprocity. In The Prague Bulletin of Mathematical Linguistics, 87, pages 27-40.

[10] Panevová, J., Hajičová, E., Kettnerová, V., Lopatková, M., Mikulová, M., and Ševčíková, M. (2014). Mluvnice současné češtiny 2, Syntax na základě anotovaného korpusu. Praha, Karolinum.

[11] Medová, L. (2009). Reflexive Clitics in the Slavic and Romance Languages. A Comparative View from an Antipassive Perspective. PhD thesis, Princeton, Princeton University.

[12] Grepl, M., and Karlík, P. (1999). Skladba češtiny. Olomouc, Votobia.

[13] Kettnerová V., and Lopatková, M. (2018). Lexicographic Potential of Syntactic Properties of Verbs: The Case of Reciprocity in Czech. In XVIII EURALEX International Congress, Lexicography in Global Contexts, pages 685-698, Ljubljana, Ljubljana University Press.

[14] Sgall, P., Hajičová, E., and Panevová, J. (1986). The Meaning of the Sentence in Its Semantic and Pragmatic Aspects. Dordrecht, Reidel.

[15] Panevová, J. (1994). Valency Frames and the Meaning of the Sentence. In P. A. Luelsdorff (ed.), The Prague School of Structural and Functional Linguistics, pages 223-243, Amsterdam/Philadelphia, John Benjamins.

[16] Dvořak, V. (2017). Verbální substantivum. In P. Karlík, M. Nekula, J. Pleskalová (eds.), Nový encyklopedický slovník češtiny. Praha, Nakladatelství Lidové noviny.

[17] Evans, N., Gaby, A., and Nordlinger, R. (2007). Valency mismatches and the coding of reciprocity in Australian languages. In Linguistic Typology, 11, pages 541-597.

[18] Kolářová, V. (2010). Valence deverbativních substantiv v češtině (na materiálu substantiv s dativní valencí). Praha, Karolinum.

[19] Dvořak, V. (2017). Dějové substantivum. In P. Karlík, M. Nekula, and J. Pleskalová (eds.), Nový encyklopedický slovník češtiny. Praha, Nakladatelství Lidové noviny.

[20] Gleitman, L. R., Gleitman, H., Miller, C., and Ostrin, R. (1996). Similar, and similar concepts. Cognition, 58, pages 321-376. 